\title{
Equine infectious anemia virus in naturally infected horses from the Brazilian Pantanal
}

\author{
Andreia Elisa Cursino ${ }^{1}$ Ana Paula Pessoa Vilela, ${ }^{1,2}$ Ana Paula Moreira Franco-Luiz ${ }^{1,3}$. \\ Jaquelline Germano de Oliveira ${ }^{4}$. Márcia Furlan Nogueira ${ }^{5}$. João Pessoa Araújo Júnior ${ }^{6}$. Daniel Moura de Aguiar ${ }^{7}$. \\ Erna Geessien Kroon ${ }^{1}$ (D)
}

Received: 21 February 2018 / Accepted: 19 March 2018 / Published online: 11 May 2018

(c) Springer-Verlag GmbH Austria, part of Springer Nature 2018

\begin{abstract}
Equine infectious anemia (EIA) has a worldwide distribution, and is widespread in Brazil. The Brazilian Pantanal presents with high prevalence comprising equine performance and indirectly the livestock industry, since the horses are used for cattle management. Although EIA is routinely diagnosed by the agar gel immunodiffusion test (AGID), this serological assay has some limitations, so PCR-based detection methods have the potential to overcome these limitations and act as complementary tests to those currently used. Considering the limited number of equine infectious anemia virus (EIAV) sequences which are available in public databases and the great genome variability, studies of EIAV detection and characterization molecular remain important. In this study we detected EIAV proviral DNA from 23 peripheral blood mononuclear cell (PBMCs) samples of naturally infected horses from Brazilian Pantanal using a semi-nested-PCR (sn-PCR). The serological profile of the animals was also evaluated by AGID and ELISA for gp90 and p26. Furthermore, the EIAV PCR amplified DNA was sequenced and phylogenetically analyzed. Here we describe the first EIAV sequences of the 5' LTR of the tat gene in naturally infected horses from Brazil, which presented with $91 \%$ similarity to EIAV reference sequences. The Brazilian EIAV sequences also presented variable nucleotide similarities among themselves, ranging from $93,5 \%$ to $100 \%$. Phylogenetic analysis showed that Brazilian EIAV sequences grouped in a separate clade relative to other reference sequences. Thus this molecular detection and characterization may provide information about EIAV circulation in Brazilian territories and improve phylogenetic inferences.
\end{abstract}

Handling Editor: Li Wu.

Electronic supplementary material The online version of this article (https://doi.org/10.1007/s00705-018-3877-8) contains supplementary material, which is available to authorized users.

Erna Geessien Kroon

ernagkroon@gmail.com; kroone@icb.ufmg.br

1 Laboratório de Vírus, Departamento de Microbiologia, Instituto de Ciências Biológicas, Universidade Federal de Minas Gerais, Belo Horizonte, MG, Brazil

2 Laboratório de Biologia Molecular, Microbiologia e Sorologia, Hospital Universitário, Universidade Federal de Santa Catarina, Florianópolis, SC, Brazil

3 Viriontech do Brasil Indústria de Insumos e Serviços em Biotecnologia, Belo Horizonte, MG, Brazil

\section{Introduction}

Equine infectious anemia (EIA) is caused by equine infectious anemia virus (EIAV), a lentivirus classified within the Retroviridae family [1], which infects equines. The EIAV genome comprises approximately $8.2 \mathrm{kbp}$, formed by gag (group specific antigen), pol (polymerase), and env (envelope) genes, and flanked at both ends by long

4 Instituto Rene Rachou, Fiocruz-Minas, Belo Horizonte, MG, Brazil

5 Embrapa Pantanal, Corumbá, MS, Brazil

6 Departamento de Microbiologia e Imunologia, Instituto de Biociências e Instituto de Biotecnologia, Universidade Estadual Paulista, UNESP, Botucatu, SP, Brazil

7 Laboratório de Virologia e Rickettsioses, Faculdade de Medicina Veterinária, Universidade Federal de Mato Grosso, Cuiabá, MT, Brazil 
terminal repeats (LTRs) [2]. EIAV possesses additional open reading frames (ORFs) S1, S2 and S3 [3]. S1 stands for tat (transcriptional transactivator), presenting two exons, one located between the 5' LTR region and the initiation site of gag gene, and the other located in the intergenic region pol-env $[4,5]$. The ORF S2 is located between the $p o l$ and $e n v$ genes, overlaying the initiation of env gene. S3 stands for rev (regulating the expression of viral proteins), overlaying the env gene [6].

EIA has a worldwide distribution [7], being one of the eleven equine diseases requiring compulsory notification to the World Organisation for Animal Health (OIE) [8]. According to the OIE EIA diagnosis [7] is made using the agar gel immunodiffusion assay (AGID), described by Coggins and Norcross in 1970. Since then this test has been considered the gold standard for serological tests, which detect antibodies against the viral capsid protein p26 [9, 10]. In addition, serology involving enzyme linked immunosorbent assays (ELISA) has also been approved for EIA diagnosis. Four ELISA kits were approved by the United States Department of Agriculture (USDA) and are internationally available for EIA diagnosis. However, the OIE states that a positive result by ELISA should be retested using the AGID to confirm diagnosis, since some false-positive results can occur with ELISA [7, 10].

EIA is widespread in Brazilian territories, and has a high prevalence in the Brazilian Pantanal, as reported previously in the Poconé municipality, state of Mato Grosso, with a seroprevalence of $31,5 \%$ by AGID test [11]. Pantanal is an ecosystem characterized by a vast flooded plain, $250.000 \mathrm{Km}^{2}$ in size, wherein nearly $60 \%$ of the area are located in the Mato Grosso and Mato Grosso do Sul states, Brazil. EIA negatively affects the performance of equines affecting the livestock activity in this area, one of the main economic activities of this region [12, 13]. Parreira et al. [14], in a study with horses in the southern region of Pantanal, showed a positive correlation between EIAV infection and horses which were used for extensive cattle ranching.

In Brazil, according to the Ministério da Agricultura, Pecurária e Abastecimento (MAPA) the diagnosis of EIA is made using AGID [15], although the use of ELISA was recently approved as a diagnostic assay for EIA [16]. However, in cases of disagreement between ELISA and AGID, the result obtained in the AGID prevails. The Brazilian law requires euthanasia of EIAV positive animals and prohibition of trade activity on ranches after identification of EIA [15]. However, in ranches within the Brazilian Pantanal positive animals can be maintained for use in livestock management on the farm, however their transit is not allowed. Concomitantly, the diagnosis and adoption of prophylactic measures and control of EIA on ranches is being promoted, through an official state program entitled "Programa de
Controle e Prevenção da Anemia Infecciosa Equina no Pantanal Sul-Mato-Grossense (CAIEPAN)" [17, 18].

Based on experimental infection of horses with EIAV, EIA can be characterized by three defined stages: acute, chronic, and long-term asymptomatic. Initial exposure to a virulent strain usually results in an acute disease characterized by fever, diarrhea, lethargy, anemia, and thrombocytopenia, associated with a high level viremia in plasma. Following this initial clinical episode, most infections typically progress to chronic EIA, characterized by repeated disease cycles at irregular intervals, and associated with viremia waves. Over time the frequency of disease episodes and the severity of clinical signals typically decrease, thus persistently infected horses become clinically asymptomatic for EIA indefinitely, reaching the asymptomatic carrier stage, remaining infected for life $[19,20]$.

The major transmission route of EIAV is mechanical through infected blood via an arthropod vector, normally the bite of blood sucking insects of the Diptera order or by contaminated fomites which can occur through bloodcontaminated instruments such as syringes, needles, surgical instruments and equine accessories [13, 21, 22]. Transplacental transmission has also been reported [23]. The virus has a tropism for macrophages, and during acute infection it can be detected in high titers mainly in the spleen, liver and lymph node tissues. Lower titers can be seen in the macrophages of other tissues, such as the kidney, lung and adrenal gland [24, 25].

Several PCR methodologies have been developed for the detection of proviral DNA and viral RNA extracted from different types of clinical samples, such as plasma, peripheral blood mononuclear cells (PBMCs) and tissues. However, these PCRs were performed using samples from experimentally infected equines with known infectious EIAV [26-32]. Some of these already described PCR assays failed to detect EIAV from field specimens in some countries, which indicates that the designed primers may not be globally specific. This suggests the occurrence of mismatches during annealing of primers and their target sequence leading to failed PCRs and false negatives [33-35].

PCRs have been developed for the detection of partial regions of the EIAV genome from a variety of samples of naturally infected horses in Canada, Ireland, Slovenia, Italy and Romania. Most of these PCRs amplify the gag gene of EIAV, by means of a reverse transcriptase PCR (RT-PCR) developed for the detection of viral RNA from plasma samples, as well as a nested PCR (n-PCR) assay for the detection of proviral DNA from PBMC samples. In some studies, it was possible to detect viral RNA and proviral DNA from other samples, such as lymph nodes, lung, liver, spleen, adrenal, thymus, and kidney tissues samples; and in nasal, oral, conjunctival and genital swabs [33, 35-38]. Recently in Brazil the partial gag gene DNA sequence was amplified 
from PBMC samples [39]. Dong et al. [34] developed a n-PCR that amplifies the 5' LTR of the tat gene region of the EIAV genome, a highly conserved region in the genome. This n-PCR was used for detection of proviral DNA from PBMC samples.

In this study the detection of EIAV proviral DNA from PBMC samples of naturally infected horses from the Brazilian Pantanal was made by a semi-nested PCR (sn-PCR) using primers that amplify the 5' LTR to exon 1 of the tat gene region. Furthermore, molecular characterization of this amplified DNA and phylogenetic analysis was performed. Considering the limited number of worldwide EIAV sequences and the absence of complete genome sequences from Brazilian EIAV available in public databases, studies concerning the detection and characterization molecular of EIAV can contribute to the knowledge of EIAV circulating in Brazil. This provides new information about EIAV genetic diversity and provides data on the epidemiology of this equine disease.

\section{Materials and methods}

\section{Clinical samples}

Whole blood samples were collected from horses used for working cattle herds. This was performed by jugular venipuncture into tubes with and without EDTA for PBMC fractionation and serum, respectively. Of the 23 samples,
17 were collected in July 2008 and five in April 2015 from horses at two farms in Nabileque and Nhecolândia, respectively, two sub-regions of the Pantanal, both belonging to Corumbá municipality of Mato Grosso do Sul State, Midwestern region of Brazil (Figure 1). One sample (POCONEBR-01) was collected in 2015 from a horse with clinical signals of EIA at a farm within the limits of the Poconé and Nossa Senhora do Livramento counties of Mato Grosso, Brazil. Serum and PBMC samples were stored at $-20{ }^{\circ} \mathrm{C}$.

\section{Compliance with ethical standards}

This study was carried out in strict accordance with the recommendations of the Brazilian National Council for Control of Animal Research (CONCEA). The Animal Research Ethical Committee approved the experimental protocols process number 195/2012. All applicable international, national, and/or institutional guidelines for the care and use of animals were followed and welfare of the involved animals was observed.

\section{Detection of proviral DNA}

\section{Nucleic acid extraction}

For PBMC fractionation, whole blood was centrifuged for 10 minutes to $1.000 \mathrm{xg}$, and the intermediate phase, corresponding to the fraction of mononuclear cells, between plasma and erythrocytes was collected. From these cells

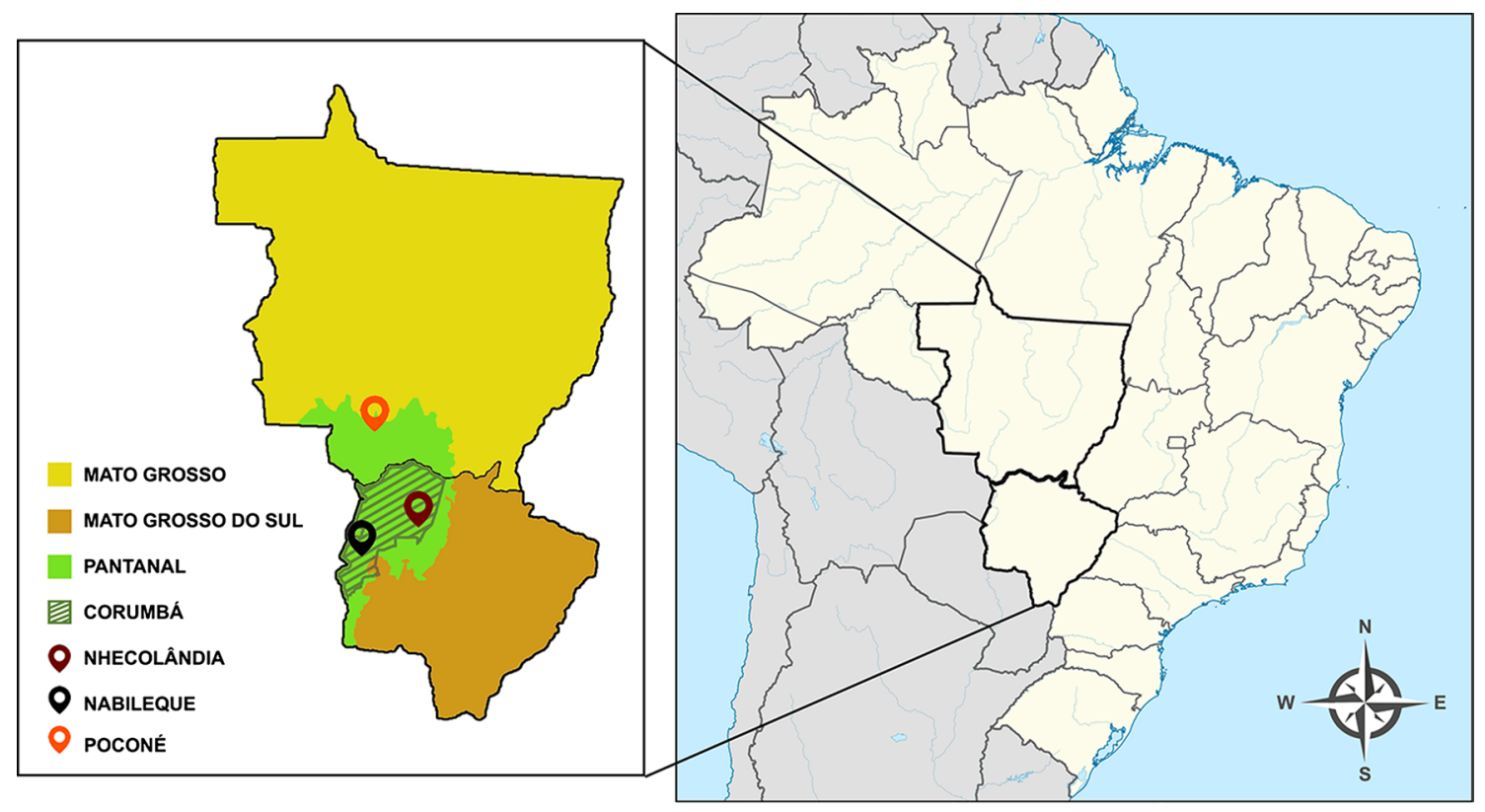

Fig. 1 Localization of Brazilian Pantanal in the Mato Grosso and Mato Grosso do Sul states - Map indicates the Brazilian state and counties in which the samples were collected: Nabileque and
Nhecolândia, subregions of Corumbá, Mato Grosso do Sul state, and Poconé county of Mato Grosso state 
proviral DNA was extracted, using the kit NucleoSpin ${ }^{\circledR}$ Blood (Macherey-Nagel, Düren, Germany), according to the manufacturer's instructions. The extracted DNA was stored at $-20{ }^{\circ} \mathrm{C}$ until analysis.

\section{Primers}

For proviral DNA detection primers targeting a sequence covering the 5' LTR region to exon 1 of the tat gene were used. The primers used were: EIAVltr-1R and EIAVltr$2 \mathrm{R}$ based on the tat gene, described by Dong et al. [34], together with the primer EIAVltr-4F, designed in Laboratório de Vírus, based on a region in the 5 ' LTR (Table 1). The primer was designed based on the 16 whole-genome sequences of EIAV available in GenBank (Figure S1). The sequences were aligned using the Clustal W in Mega version 6.0 [40]. Subsequently, the specific primer was designed and analyzed using the OligoAnalyzer 3.1 program (Integrated DNA Technologies) [https://www.idtdna.com/calc/analy zer]. It was analyzed for sequence similarity with sequences deposited in the National Center for Biotechnology Information (NCBI), by the tool nucleotide BLAST (nBLAST) within the Basic Local Alignment Search Tool program (BLAST) [41].

\section{Semi-nested-PCR (sn-PCR)}

The PCR was performed with the outer primer set (EIAVltr4F and EIAVltr-1R), which amplifies a fragment of about 210 base pairs. This PCR product was used as template for a semi-nested PCR (sn-PCR), that was performed with the outer primer EIAVltr-4F and an inner primer EIAVltr$2 \mathrm{R}$, which amplifies a fragment of about 185 base pairs (Table 1). The PCR and sn-PCR were made using the kit GoTaq ${ }^{\circledR}$ Hot Start Colorless Master Mix (Promega, Madison, WI, USA). For one reaction the following concentrations were used: $1 \mathrm{X}$ of $\mathrm{GoTaq}^{\circledR}{ }^{\circledR}$ Hot Start Colorless Master Mix, nuclease-free water, each forward and reverse primer to a final concentration of $0,5 \mu \mathrm{M}$, and template DNA at a concentration of ten percent of the final volume of the reaction. The optimal annealing temperature of the primers was determined by gradient PCR with temperatures of $60{ }^{\circ} \mathrm{C}$, and $58{ }^{\circ} \mathrm{C}$ to $52^{\circ} \mathrm{C}$. The PCR consists of an initial denaturation step at $95{ }^{\circ} \mathrm{C}$ for 2 minutes, followed by 40 cycles of $94{ }^{\circ} \mathrm{C}$ for 30 seconds, an annealing temperature step at $58{ }^{\circ} \mathrm{C}$ for 30 seconds, $72{ }^{\circ} \mathrm{C}$ for 30 seconds, and a final extension of $72{ }^{\circ} \mathrm{C}$ for 3 minutes. The sn-PCR consists of an initial denaturation step at $95^{\circ} \mathrm{C}$ for 2 minutes, followed by 35 cycles of $94{ }^{\circ} \mathrm{C}$ for 30 seconds, an annealing temperature step at $60^{\circ} \mathrm{C}$ for 30 seconds, $72^{\circ} \mathrm{C}$ for 30 seconds, and a final extension of $72{ }^{\circ} \mathrm{C}$ for 5 minutes. A control was performed using the same reagents (except genomic DNA) in the same concentrations. Five micro liters of amplified DNA were analyzed by electrophoresis in $8 \%$ polyacrylamide gels (PAGE). For inference of the amplified fragments size a ladder of 100 base pairs was used (Ludwig Biotec, Rio Grande do Sul, Brazil). PAGE was performed at $100 \mathrm{~V}$ using the $1 \mathrm{X}$ Tris/ Borate/EDTA buffer (TBE) and stained with silver nitrate (Merck, Darmstadt, Germany). Reactions where an amplified DNA fragment with the expected size in the sn-PCR was generated were considered positive.

\section{Sequencing}

The sn-PCR generated fragments were sequenced to ensure their authenticity and for subsequent phylogenetic analysis. For sequencing, products generated in the sn-PCR were fractionated in a PAGE $8 \%$ and stained using $\mathrm{SYBR}^{\circledR}$ Gold Nucleic Acid Gel Stain (Invitrogen, CA, USA). The fragment of the expected size was excised from the gel with a scalpel blade and purified prior to sequencing. The samples were sequenced using the same primers as for the sn-PCR.

The nucleotide sequences were determined according to the method of dideoxy described by Sanger et al. [42] in an automatic capillary sequencer "ABI 3730 DNA Analyzer" (Applied Biosystems, CA,USA), using the kit "BigDye ${ }^{\circledR}$ Terminator v3.1 Cycle Sequencing (Applied Biosystems, CA, USA), according to reaction and reading conditions indicated by the manufacturer. The nucleotide sequences obtained were analyzed, assembled and edited using the program SeqTrace 0.9.0 [43]. The sequences were compared with deposited sequences in the National Center for

Table 1 Primers used in semi-nested-PCR

\begin{tabular}{|c|c|c|c|c|}
\hline & Primer & Oligonucleotide Sequence & $\begin{array}{l}\text { Annealing Tempera- } \\
\text { ture }\end{array}$ & $\begin{array}{l}\text { Amplicon } \\
\text { Length } \\
\text { (bp) }\end{array}$ \\
\hline \multirow{2}{*}{$\begin{array}{l}\text { Outer primers } \\
\text { for PCR }\end{array}$} & EIAVltr-4 Forward & 5' - GTCCCTTCTCTGCTGGGCTA - 3' & \multirow[t]{2}{*}{$58^{\circ} \mathrm{C}$} & \multirow[t]{2}{*}{210} \\
\hline & EIAVltr-1 Reverse* & 5' - CAGGAACACCTCCAGAAGAC - 3' & & \\
\hline \multirow{2}{*}{$\begin{array}{l}\text { Inter primers } \\
\text { for snPCR }\end{array}$} & EIAVltr-4 Forward & 5' - GTCCCTTCTCTGCTGGGCTA - 3' & \multirow[t]{2}{*}{$60^{\circ} \mathrm{C}$} & \multirow[t]{2}{*}{185} \\
\hline & EIAVltr-2 Reverse* & 5' - TAAGTTCTCCTCTGCTGTCC - 3' & & \\
\hline
\end{tabular}

Nucleotide sequence of primers, their annealing temperature, and the amplicon length for PCR and snPCR. *These primers were described by Dong et al. [34] 
Biotechnology Information (NCBI) [http://www.ncbi.nlm. nih.gov/] using the nucleotide BLAST (nBLAST) tool within the Basic Local Alignment Search Tool (BLAST) [41] [http://blast.ncbi.nlm.nih.gov/Blast.cgi]. The estimated nucleotide similarity between sequences was made in the Mega program, version 6.0 [40], employing the p-distance method that estimates evolutionary divergence between sequences.

\section{Phylogenetic analysis}

A phylogenetic tree was constructed using nucleotide sequences aligned by Clustal W in Mega version 6, with 16 reference sequences representing EIAV complete genomes and three partial sequences of EIAV from Genbank. To determine the best evolutionary model the jModel test [44] was used. The phylogenetic analysis was performed in the Mega program, version 6.0 [40] employing the Maximum Likelihood statistical method along with the General Time Reversible model and Gama distributed with invariant sites. Bootstrap values were determined over 1000 replicates. At the end the phylogenetic tree was previewed in the FigTree version 1.4.2 - Tree Figure Drawing Toll.

\section{Serological assays}

AGID (Bruch, São Paulo, Brazil) and ELISA for p26 (Viriontech do Brasil, Belo Horizonte, Brazil) (unpublished data) and gp90 (Biostream do Brasil, Belo Horizonte, Brazil) were performed for all serum samples, according to manufacturer's instructions.

\section{Results}

\section{Semi-nested-PCR and nucleotide sequences}

Amplified DNA of the expected size in the sn-PCR was detected in PBMCs from naturally infected horses. Optimal annealing temperatures for the PCR and sn-PCR were determined as $58^{\circ} \mathrm{C}$ and $60{ }^{\circ} \mathrm{C}$, respectively. Amplified DNA was obtained from 23 samples and sequenced. The nucleotide sequences had identity with other EIAV sequences previously published in GenBank. The alignment of Brazilian EIAV nucleotide sequences with sequences from China, Japan, Ireland, United States, Italy and Mongolia showed conserved regions of nucleotides and short regions of nucleotide deletions, substitutions and insertions (Figure 2). The Brazilian EIAV sequences presented high nucleotide similarities among themselves, ranging from $93,5 \%$ to $100 \%$. Moreover, Brazilian Pantanal EIAV sequences, when compared to other EIAV sequences presented variable rates of conservation, ranging from $85,4 \%$ to $89,1 \%$ with Wyoming,
$85,4 \%$ to $88,1 \%$ with Liaoning, $82,4 \%$ to $86,2 \%$ Miyazaki, $87,1 \%$ to $90,7 \%$ with $\mathrm{H} 3,86,2 \%$ to $89,8 \%$ with Ita- $1,87,9 \%$ to $90,7 \%$ with Mongolia-1 and $84,3 \%$ to $87,1 \%$ with Mongolia-2 (Figure S2).

\section{Phylogenetic analysis}

The phylogenetic analysis was performed with the 23 EIAV sequences of about 144 nucleotides in length which were compared to the same region in 16 reference sequences representing the EIAV complete genome as well as three partial sequences of EIAV from Genbank. The phylogenetic tree showed that Brazilian EAIV sequences grouped in a separate clade supported by a bootstrap value of 90 . The sequences of viruses from China, United States, Ireland, Japan and Mongolia form five separate clades, while the Italian sequences grouped together with the Irish sequences. All clades were supported by a high bootstrap value which corroborates the literature [45] (Figure 3).

\section{Serological status of the sn-PCR positive equines}

Of the 23 samples positive by snPCR, $91 \%$ were positive in AGID while $100 \%$ were positive by ELISA against p26 or gp90. Samples PAN-BR-10 and PAN-BR-12 were negative and undetermined for AGID, respectively, but positive for ELISA gp90 (Table 2).

\section{Discussion}

EIA is routinely diagnosed by the AGID test, which present limitations for the detection of EIAV infection. The serodiagnosis evaluates the presence of antibodies which is dependent on a host response immune. False negative reactions may occur as a result of recent infections, since in this disease stage the levels of antibodies may be very low or even undetectable. However, these animals may serve as potential sources of EIAV transmission [10, 46, 47]. Therefore, it is essential that detection methods for EIA become more sensitive and specific to the virus. Molecular assays to detect viral RNA or provirus DNA could be used in recently infected equines, and also to confirm EIAV infection in animals with equivocal serological results [36, 47].

The modified sn-PCR reaction in this study (derived from the n-PCR developed by Dong et al. [34]) was efficient, since it allowed the detection of EIAV proviral DNA in PBMC samples from naturally infected horses in the Brazilian Pantanal. The primers used are those described by Dong et al. [34] combined with a primer designed in our laboratory which we showed could amplify a partial region of the EIAV genome, a nucleotide sequence which extends from the 5' LTR region to the tat gene. 
Wyoming

Liaoning

Miyazaki H3

Ita-1

Mongolia-1

Mongolia-2

PAN-BR-01

PAN-BR-02

PAN-BR-03

PAN-BR-0 4

PAN-BR-0 5

PAN-BR-06

PAN-BR-07

PAN-BR-0 8

PAN-BR-09

PAN-BR-10

PAN-BR-11

PAN-BR-12

PAN-BR-13

PAN-BR-14

PAN-BR-15

PAN-BR-16

PAN-BR-17

PAN-BR-18

PAN-BR-19

PAN-BR-20

PAN-BR-21

PAN-BR-22

POCONE-BR-01

Wyoming

Liaoning

Miyazaki

H3

Ita-1

Mongolia-1

Mongolia-2

PAN-BR-01

PAN-BR-02

PAN-BR-03

PAN-BR-0 4

PAN-BR-0 5

PAN-BR-06

PAN-BR-07

PAN-BR-08

PAN-BR-09

PAN-BR-10

PAN-BR-11

PAN-BR-12

PAN-BR-13

PAN-BR-14

PAN-BR-15

PAN-BR-16

PAN-BR-17

PAN-BR-18

PAN-BR-19

PAN-BR-20

PAN-BR-21

PAN-BR-22

POCONE-BR-01
AAAGECCTTT GT AATAAATA TA- ATTCTC TA-CFCAGTC CCTGTCTCTA GTTPETCT-- -GTTCGA-GA TACTA

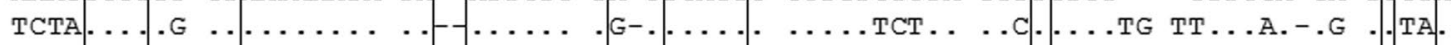
$\ldots$ TA $\ldots . . .6$.

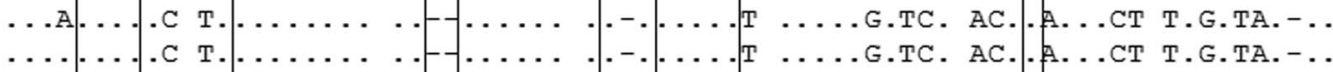

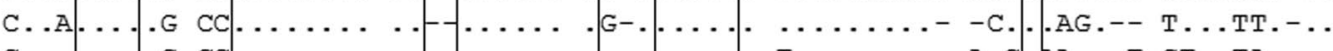

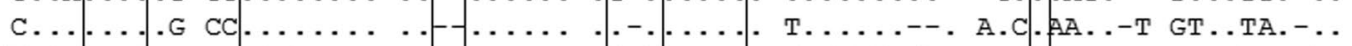

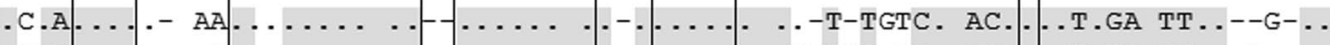

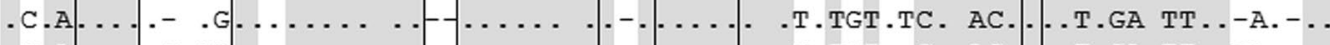
.C.A.....G AA . Т.А.... . . . . . . . .

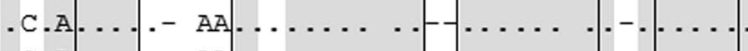
C.A. .C.A..... .G.

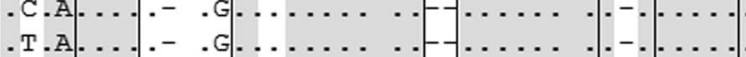
.C.A. C.A......- An .C.A.....- .G.

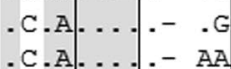
C.A. . C.A. -....- AA - Т.A.....- .G. . T.A. C.A. .... A- A. .C.A. ....G- A. .

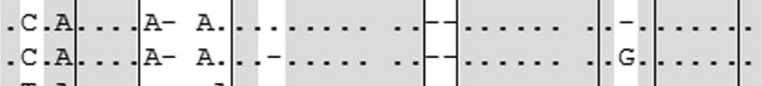
.T-TGT..C. AC. ..T.GA TT..TA.-. .T.TGT.TC. AC. -.T.GA TT..-A.-. ..-T-TGTC. AC. . .T.GA TT..--G-.. ..-T-TGTC. AC. . . T.GA TT..--G-. .T.TGT.TC. AC. - .T.GA TT..-A.-. .T.TGT.TC. AC. - . T.GA TT . .-A.-. .T.TGT.TC. AC. . .T.GA TT..-A.-. ..-T-TGTC. AC. . . .T.GA TT..--G-.. -T.TGT.TC. AC. . .T.GA TT..-A.-. -T.TGT.TC. AC. . . T.GA TT..-A.-. ..-T-TGTC. AC. -. T.GA TT...--G-. .T.TGT.TC. AC. -.T.GA TT..-A.-. ..-T-TGTC. AC. ..T.GA TT..--G-.. .T.TGT.TC. AC. -..T.GA TT..-A.-. .T.TGT.TC. AC. -.T.GA TT..-A.-. .TGTGT.TC. AC. -..T.GG TT..-A.-. .TGTGT.TC. AC. -..T.GG TT..-A.-.. .T-TGT.TC. AC. -.T.GA TT..-A.-. .TGTGT.TC. AC. -.T.GG TT..-A.-.. ..-TGT.TC. AC. -.T.GA TT..-A.-. ...TGTCTC. AC. ...T-GG TT..-A.-.

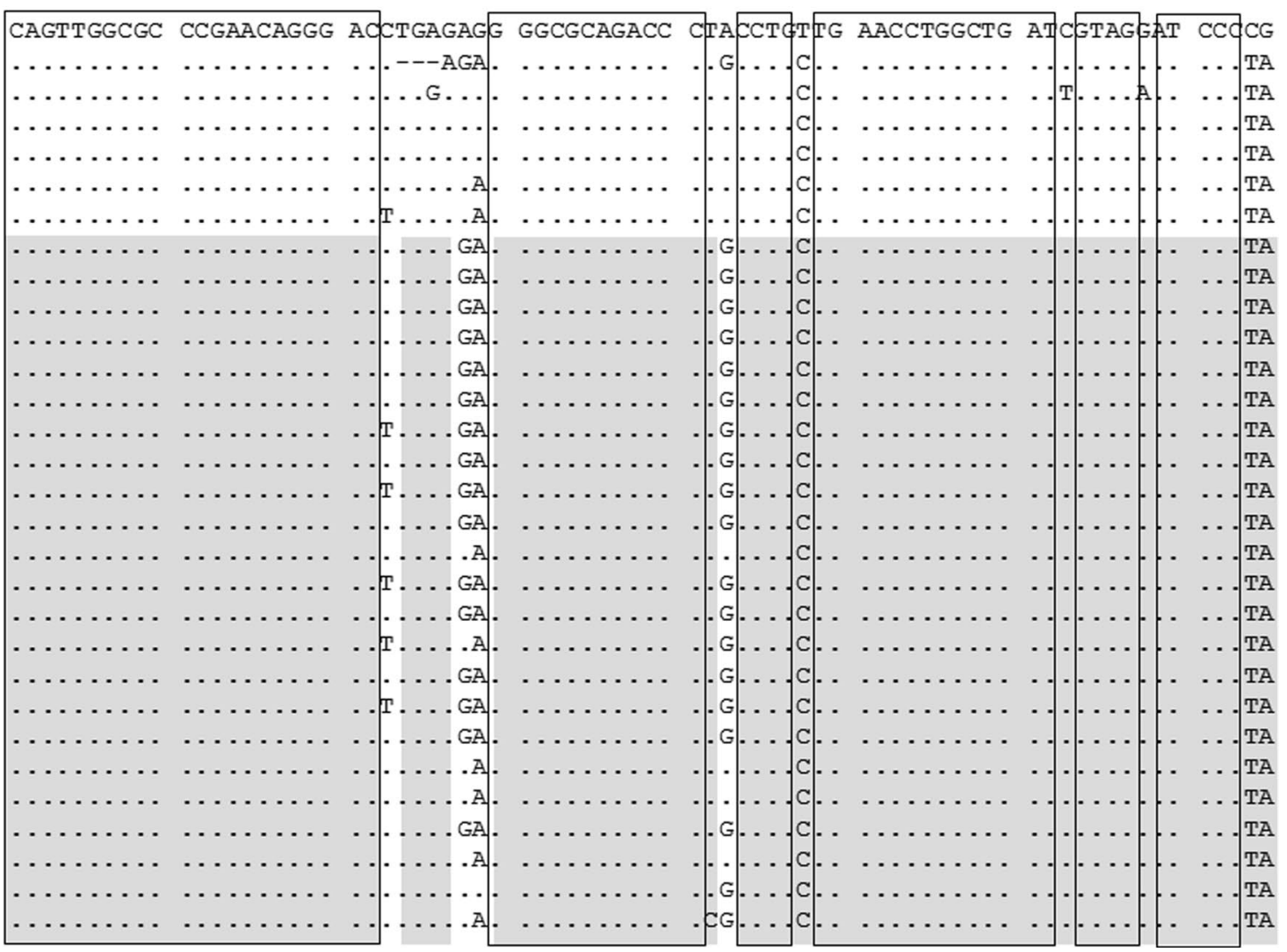


4Fig. 2 Brazilian Pantanal proviral EIAV nucleotide sequence alignment. Alignment of EIAV sequences of about 144 nucleotides in length obtained from amplification of proviral DNA from Brazilian Pantanal EIAV, together with seven EIAV reference sequences: Wyoming (AF033820.1), Liaoning (AF327877.1), Miyazaki 2011-A (JX003263.1), H3 (JX480634.1), Ita1 (EU240733.1), Mongolia-1 (LC185347.1) and Mongolia-2 (LC190840.2). The alignment was performed in the Mega program, version 6.0 [40]. Conserved regions in all sequences are boxed, while conserved regions found only in Brazilian Pantanal EIAV sequences are shown in grey

Low viral load in plasma and target tissues during the different stages of disease, especially when the animal reaches the asymptomatic carrier stage can influence nucleic acid detection in molecular assays. As demonstrated by Harrold et al. [28] in a study with experimentally infected equines the acute EIA phase was associated with high levels of viral RNA in plasma, in contrast in the asymptomatic phase which was associated with undetectable or very low detectable levels of plasma viral RNA, as measured by RT-PCR. However, Cappelli et al. [33], in a study using samples from naturally infected horses, suggest that amplification of proviral DNA extracted from whole blood samples by n-PCR is a more sensitive indicator of EIAV infection than viral RNA in plasma by RT-PCR. Dong et al. [34] also demonstrated amplification of proviral DNA from PBMC samples in naturally infected horses which had no EIA clinical signs at the time the samples were collected, indicating that most if not all horses had already entered the asymptomatic carrier stage.

Extensive nucleotide variability in EIAV from geographically distinct viruses may favor the occurrence of mismatches between diagnostic primers and target sequences,

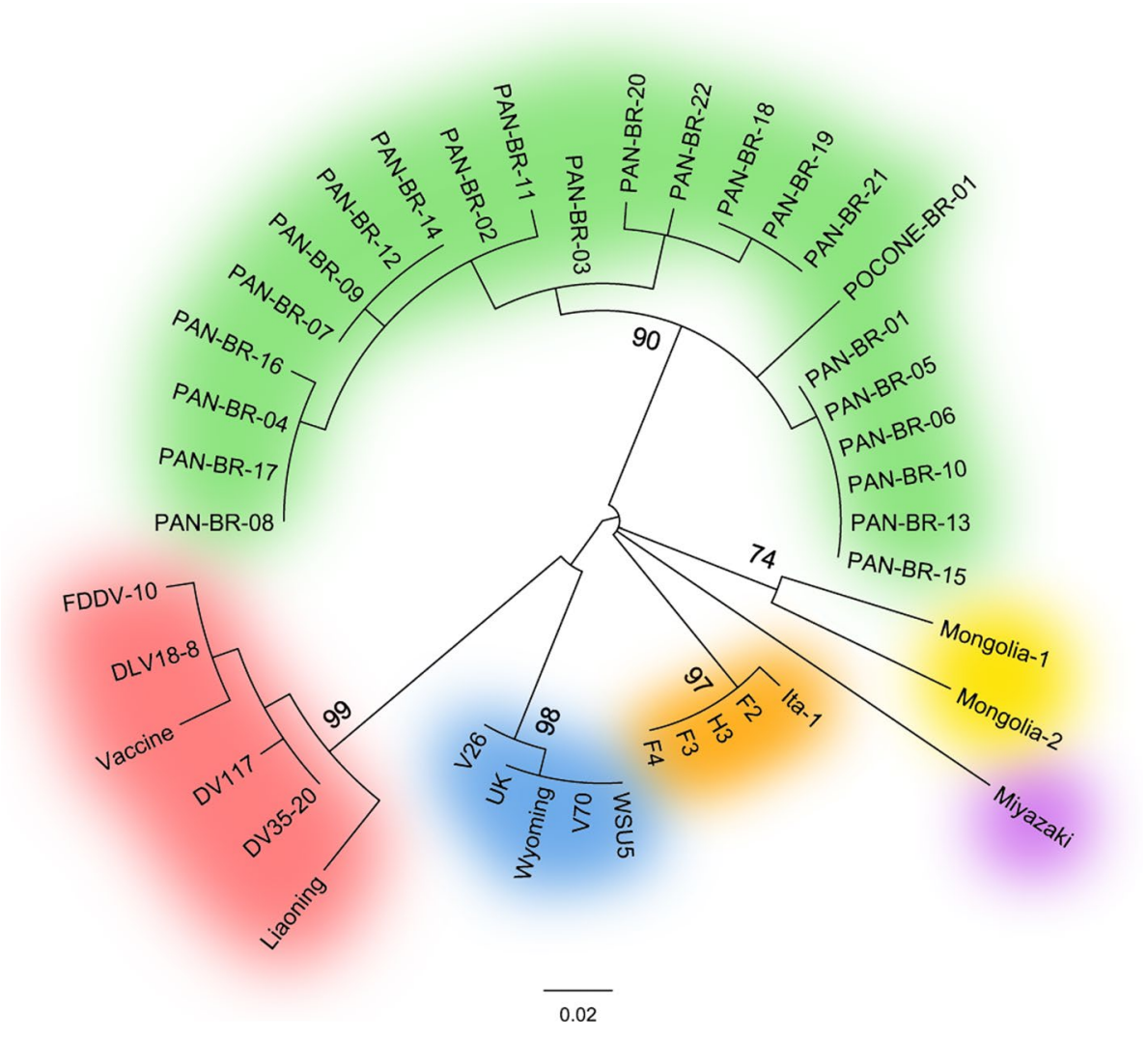

Fig. 3 Phylogenetic analysis of Brazilian Pantanal proviral EIAV nucleotide sequences. Phylogenetic analysis was performed based on 23 Brazilian EIAV sequences of about 144 nucleotides in length, isolated from proviral DNA amplified by sn-PCR. The phylogenetic analysis was performed together with 19 EIAV complete genome sequences, available in GenBank: H3 (JX480634.1), F4 (JX480633.1), F3 (JX480632.1), F2 (JX480631.1), Liaoning (AF327877.1), Vaccine (AF327878), DV117 (HM141912.1), DLV18-8 (HM141923.1), DV35-20 (HM141911.1), FDDV-10 (GU385360.1), Wyoming (AF033820.1), EIAVuk (AF016316.1),
WSU5 (AF247394.1), V26 (AB008197.1), V70 (AB008196.1), Miyazaki 2011-A (JX003263.1), Ita1 (EU240733.1), Mongolia-1 (LC185347.1) and Mongolia-2 (LC190840.2). The phylogenetic tree was inferred by the Maximum Likelihood statistical method along with the General Time Reversible model and Gama distributed with invariant sites using MEGA version 6.0 [40] program. Bootstrap values were determined over 1000 replicates. Within the tree the six clusters representing Brazil, China, United States, Ireland and Italy, Japan and Mongolia sequences are highlighted by the colors green, red, blue, orange, purple and yellow, respectively (color figure online) 
Table 2 Results of semi-nested-PCR and serological assays

\begin{tabular}{lllll}
\hline SAMPLE & sn-PCR & AGID & ELISA gp90 & ELISA p26 \\
\hline PAN-BR-01 & + & + & + & + \\
PAN-BR-02 & + & + & + & - \\
PAN-BR-03 & + & + & + & + \\
PAN-BR-04 & + & + & + & + \\
PAN-BR-05 & + & + & + & + \\
PAN-BR-06 & + & + & + & + \\
PAN-BR-07 & + & + & + & + \\
PAN-BR-08 & + & + & + & + \\
PAN-BR-09 & + & + & + & + \\
PAN-BR-10 & + & - & + & + \\
PAN-BR-11 & + & + & + & + \\
PAN-BR-12 & + & $\mathrm{U}$ & + & + \\
PAN-BR-13 & + & + & + & + \\
PAN-BR-14 & + & + & - & + \\
PAN-BR-15 & + & + & + & + \\
PAN-BR-16 & + & + & + & + \\
PAN-BR-17 & + & + & + & + \\
PAN-BR-18 & + & + & + & + \\
PAN-BR-19 & + & + & - & + \\
PAN-BR-20 & + & + & + & + \\
PAN-BR-21 & + & + & + & + \\
PAN-BR-22 & + & + & + & + \\
\hline
\end{tabular}

$(+)$ indicates a positive result, (-) indicates a negative result, and (U) indicates an undetermined result in AGID and ELISA tests

making it difficult to obtain a primer which could be suitable for global EIAV detection. This is seen as a major obstacle to the routine implementation of a PCR based diagnostic method $[34,46]$. Although molecular methods represent a highly sensitive alternative for EIAV detection, these techniques require extensive nucleotide sequence information, thus there is an urgent need for EIAV genome characterization from isolates in different regions of the world [33, 48].

Although EIA was first described about 150 years ago, very little is known about the genetic diversity of EIAV, excepting for some partial sequences of the gag gene which have been published. To date only four EIAV complete genome sequences from field samples have been published, amongst them the EIAV Wyoming, isolated in United States [49]; and the EIAV Liaoning, isolated in China [50]. All the other EIAV complete genome sequences are clones of these viruses generated in the laboratory [45, 50-54]. In 2013, two new sequences, the Miyazaki 2011-A, isolated in Japan [55], and the $\mathrm{EIAV}_{\text {IRE }}$ strain, isolated in Ireland [56] were published. Recently in 2017 Cappelli et al. [48] sequenced approximately 95\% of the proviral DNA of an EIAV strain from an outbreak that occurred in Italy in 2006. Until now there have been no complete Brazilian EIAV genome sequences available in the public databases. Recently in
2017 fifteen sequences representing 393 nucleotides of the gag gene from horses in Bahia-Brazil were published [39].

The 23 Brazilian EIAV nucleotide sequences we obtained covering the 5' LTR region to the tat gene are the first such sequences described for this genomic region. These sequences have variable nucleotide similarity to each other, ranging from $93,5 \%$ to $100 \%$. When compared to EIAV sequences from other regions of the world, this similarity ranges from $82,4 \%$ to $90,7 \%$. Phylogenetic analysis showed that Brazilian Pantanal sequences clustered separately from these sequences. As shown in other papers examining the phylogenetic diversity of complete genome EIAV sequences from United States, China, Japan and Ireland separate monophyletic groups were formed, suggesting a strong pattern of clustering based on geographical location $[55,56]$. Similar patterns of clustering based on geographical location were also reported by Capomaccio et al. [57], using phylogenetic analysis of the EIAV gag gene of European, Asian and American sequences. Phylogenetic analysis of 22 Slovenian sequences covering 222 nucleotides of the 5' LTR region and the gag gene, showed clustering together and the separation of Chinese and American sequences [37]. Also, phylogenetic analysis of 50 French sequences covering about 1.400 nucleotides of the gag gene clustered separating Chinese, American and Asian sequences from other European region sequences [58].

In contrast, phylogenetic analysis of two Mongolian EIAV sequences, detected using the primers described by Dong et al. [34] targeting the 5' LTR region to tat gene, revealed sequences which were similar to European sequences isolated in countries such as Hungary, Slovenia and Ireland [59]. For the Brazilian sequences from horses in Bahia-Brazil the phylogenetic analysis suggested that these EIAV sequences grouped together with American sequences WSU5, UK and Wyoming [39]. Thus, these studies highlight the amount of genetic variation that exists between different samples of EIAV.

Detection of EIA through molecular methods may contribute to disease incidence data, which can be underestimated in regions where the disease is endemic, as well as the detection of new outbreaks of EIA for which control measures could be taken to avoid disease spread. The molecular characterization of the EIAV from different regions of the world will improve our knowledge of the virus genome, and improve primer design, which will contribute to the development of PCRs targeting different regions of the genome.

The Brazilian Pantanal sequences will contribute to information on EIAV circulation in Brazilian territories. This work contributes significantly to new information about EIAV genetic diversity and provides data for epidemiological studies of EIA incidence in Pantanal and Brazil. Considering the high incidence of EIA in the Brazilian Pantanal and the importance of equines for extensive 
livestock activity in this region, we need more effective methods for EIA detection [18]. Our studies shed light on the circulation of EIAV in the Pantanal and provide tools for molecular characterization of these viruses.

Funding This study was funded by Empresa Brasileira de Pesquisa Agropecuária (EMBRAPA - Grant 02.12.01.030.00.00), Conselho Nacional de Desenvolvimento Científico e Tecnológico (CNPq - Grant 307423/2015-8), Fundação de Amparo à Pesquisa do Estado de Minas Gerais (FAPEMIG), Fundação de Amparo à Pesquisa do Estado de Mato Grosso (FAPEMAT - 330980/2012). EGK, JPAG and DMA are fellows from $\mathrm{CNPq}$.

\section{Compliance with ethical standards}

Conflict of interest The authors declare that they have no conflict of interest.

\section{References}

1. International Committee on Taxonomy of Viruses (ICTV) (2017) Retroviridae. https://talk.ictvonline.org/taxonomy/. Accessed 09 May 2018

2. Kawakami T, Sherman L, Dahlberg J, Gazit A, Yaniv A, Tronick SR, Aaronson SA (1987) Nucleotide sequence analysis of equine infectious anemia virus proviral DNA. Virology 158:300-312

3. Rushlow K, Olsen K, Stiegler G, Payne SL, Montelaro RC, Issel CJ (1986) Lentivirus genomic organization: the complete nucleotide sequence of the env gene region of equine infectious anemia virus. Virology 155:309-321

4. Dorn P, Da Silva L, Martarano L, Derse D (1990) Equine infectious anemia virus tat: insights into the structure, function, and evolution of Lentivirus trans-activator proteins. J Virol 64:1616-1624

5. Sherman L, Gazit A, Yaniv A, Kawakami T, Dahlberg JE, Tronick SR (1988) Localization of sequences responsible for trans-activation of the equine infectious anemia virus long terminal repeat. $\mathrm{J}$ Virol 62:120-126

6. Stephens RM, Derse D, Rice NR (1990) Cloning and characterization of cDNAs encoding Equine infectious anemia virus tat and putative Rev proteins. J Virol 64:3716-3725

7. OIE Terrestrial manual 2013. Chapter 2.5.6 Equine infectious anaemia. World Organisation for Animal Health. http://www.oie. int/fileadmin/Home/eng/Health_standards/tahm/2.05.06_EIA.pdf. Accessed 09 May 2018

8. OIE-Listed diseases, infections and infestations in force in 2018. In: World Organisation for Animal Health. http://www.oie.int/en/ animal-health-in-the-world/oie-listed-diseases-2018/. Accessed 09 May 2018

9. Coggins L, Norcross NL (1970) Immuno-diffusion reaction in equine infectious anemia. Cornell Vet 60:330-335

10. Issel CJ, Cook RF (1993) A review of techniques for the serologic diagnosis of equine infectious anemia. J Vet Diagn Investig 5:137-141

11. Borges AMCM, Silva LG, Nogueira MF, Oliveira ACS, Segri NJ, Ferreira F, Witter R, Aguiar DM (2013) Prevalence and risk factors for Equine Infectious Anemia in Poconé municipality, northern Brazilian Pantanal. Res Vet Sci 95:76-81. https://doi. org/10.1016/j.rvsc.2013.02.011

12. Bazzo JC, De Freitas DAF, De Silva MLN, Cardoso EL, Santos SA (2012) Aspectos Geofísicos e Ambientais do Pantanal da Nhecolândia. Revista de Geografia (UFPE) 29:141-161
13. Silva RAMS, Abreu UGP de, Barros ATM de (2001). Anemia Infecciosa Eqüina: Epizootiologia, Prevenção e Controle no Pantanal. Corumbá: Embrapa Pantanal (Embrapa Pantanal. Circular Técnica, 29). https://www.infoteca.cnptia.embrapa.br/bitstream/ doc/807376/1/CT29.pdf. Accessed 09 May 2018

14. Parreira DR, Jansen AM, Abreu UGP, Macedo GC, Silva ARS, Mazur C, Andrade GB, Herrera HM (2016) Health and epidemiological approaches of Trypanosoma evasins ande quine infectious anemia vírus in naturally infected horses at sourthern Pantanal. Acta Tropica 163:98-102. https://doi.org/10.1016/j.actatropic a.2016.08.005

15. Instrução Normativa $N^{\circ} 45$, de 15 de Junho de 2004. Ministério da Agricultura, Pecuária e Abastecimento (MAPA). http://extranet. agricultura.gov.br/sislegis-consulta/consultarLegislacao.do?opera cao=visualizar\&id=8136. Accessed 09 May 2018

16. Normas para credenciamento e monitoramento de laboratórios de diagnóstico de anemia infecciosa equina. PORTARIA N ${ }^{\circ} 378$, DE 17 DE DEZEMBRO DE 2014, SECRETARIA DE DEFESA AGROPECUÁRIA DO MINISTÉRIO DA AGRICULTURA PECUÁRIA E ABASTECIMENTO. http://www3.servicos. ms.gov.br/iagro_ged/pdf/2337_GED.pdf. Accessed 09 May 2018

17. Nogueira MF, Oliveira JM, Santos CJS, Petzold HV, Aguiar DM, Juliano RS, Reis JKP, Abreu UGP (2017) Equine infectious anaemia in equids of Southern Pantanal, Brazil: seroprevalence and evaluation of the adoption of a control programme. Pesquisa Veterinária Brasileira 37:227-233

18. Silva RAMS, Barros ATM, Costa Neto AA, Lopes N, Cortada VMC, Matsuura TM de SM, Feldens O, Mori AE, Madureira J, Santos SAA de P, Bandini O (2004) Programa de prevenção e controle da anemia infecciosa equina no Pantanal sul-mato-grossense. Corumbá, Embrapa Pantanal. https://www.embrapa.br/busca-depublicacoes/-/publicacao/812061/programa-de-prevencao-e-contr ole-da-anemia-infecciosa-equina-no-pantanal-sul-mato-grossense. Accessed 09 May 2018

19. Leroux C, Cadoré JL, Montelaro RC (2004) Equine infectious anemia virus (EIAV): what has HIV's country cousin go to tell us? Vet Res 35:485-512

20. Craigo JK, Montelaro RC (2013) Lessons in AIDS vaccine development learned from studies of equine infectious, anemia virus infection and immunity. Viruses 5:2963-2976. https://doi. org/10.3390/v5122963

21. Issel CJ, Rushlow K, Foil LD, Montelaro RC (1988) A perspective on equine infectious anemia with an emphasis on vector transmission and genetic analysis. Vet Microbiol 17:251-286

22. Mealey RH (2007) Equine infection anemia. In: Sellon DC, Long M (eds) Equine infectious diseases. Saunders Elsevier, St. Louis, pp 213-219

23. Gregg K, Polejaeva I (2009) Risk of equine infectious anemia virus disease transmission through in vitro embryo production using somatic cell nuclear transfer. Theriogenology 72:289-299. https://doi.org/10.1016/j.theriogenology.2009.03.009

24. McGuire TC, Crawford TB, Henson JB (1971) Immunofluorescent localization of equine infectious anemia virus in tissue. Am J Pathol 62:283-294

25. Sellon DC, Perry ST, Coggins L, Fuller FJ (1992) Wild-type equine infectious anemia virus replicates in vivo predominantly in tissue macrophages, not in peripheral blood monocytes. J Virol 66:5906-5913

26. Cook SJ, Cook RF, Montelaro RC, Issel CJ (2001) Differential responses of Equus caballus and Equus asinus to infection with two pathogenic strains of equine infectious anemia virus. Vet Microbiol 79:93-109

27. Cook RF, Cook SJ, Li FL, Montelaro RC, Issel CJ (2002) Development of a multiplex real-time reverse transcriptase-polymerase chain reaction for equine infectious anemia virus (EIAV). J Virol Methods 105:171-179 
28. Harrold SM, Cook SJ, Cook RF, Rushlow KE, Issel CJ, Montelaro RC (2000) Tissue sites of persistent infection and active replication of equine infectious anemia virus during acute disease and asymptomatic infection in experimentally infected equids. J Virol 74:3112-3121

29. Kim CH, Casey JW (1992) Genomic variation and segregation of equine infectious anemia virus during acute infection. J Virol 66:3879-3882

30. Lichtenstein DL, Issel CJ, Montelaro RC (1996) Genomic quasispecies associated with the initiation of infection and disease in ponies experimentally infected with equine infectious anemia virus. J Virol 70:3346-3354

31. Oaks JL, McGuire TC, Ulibarri C, Crawford TB (1998) Equine infectious anemia virus is found in tissue macrophages during subclinical infection. J Virol 72:7263-7269

32. Whetter L, Archambault D, Perry S, Gazit A, Coggins L, Yaniv A, Clabough D, Dahlberg J, Fuller F, Tronick S (1990) Equine infectious anemia virus derived from a molecular clone persistently infects horses. J Virol 64:5750-5756

33. Cappelli K, Capomaccio S, Cook FR, Felicetti M, Marenzoni ML, Coppola G, Verini-Supplizi A, Coletti M, Passamonti F (2011) Molecular detection, epidemiology, and genetic characterization of novel European field isolates of equine infectious anemia virus. J Clin Microbiol 49:27-33. https://doi.org/10.1128/JCM.01311-10

34. Dong J-B, Zhu W, Cook FR, Goto Y, Horii Y, Haga T (2012) Development of a nested PCR assay to detect equine infectious anemia proviral DNA from peripheral blood of naturally infected horses. Arch Virol 157:2105-2111. https://doi.org/10.1007/s0070 5-012-1406-8

35. Nagarajan MM, Simard C (2001) Detection of horses infected naturally with equine infectious anemia virus by nested polymerase chain reaction. J Virol Methods 94:97-109

36. Cullinane A, Quinlivan M, Nelly M, Patterson H, Kenna R, Garvey M, Gildea S, Lyons P, Flynn M, Galvin P, Neylon M, Jankowska K (2007) Diagnosis of equine infectious anaemia during the 2006 outbreak in Ireland. Vet Rec 161:647-652

37. Kuhar U, Završnik J, Toplak I, Malovrh T (2014) Detection and molecular characterisation of equine infectious anaemia virus from field outbreaks in Slovenia. Equine Vet J 46:386-391. https ://doi.org/10.1111/evj.12138

38. Quinlivan M, Cook RF, Cullinane A (2007) Real-time quantitative RT-PCR and PCR assays for a novel European field isolate of equine infectious anemia virus based on sequence determination of the gag gene. Vet Rec 160:611-618

39. Tigre DM, Brandão CF, de Paula FL, Chinalia FA, Campos GS, Sardi SI (2017) Characterization of isolates of equine infectious anemia virus in Brazil. Arch Virol 162:873-877. https://doi. org/10.1007/s00705-016-3172-5

40. Tamura K, Stecher G, Peterson D, Filipski A, Kumar S (2013) MEGA6: Molecular evolutionary genetics analysis version 6.0. Mol Biol Evol 30:2725-2729. https://doi.org/10.1093/molbev/ mst197

41. Altschul SF, Gish W, Miller W, Myers EW, Lipman DJ (1990) Basic local Alignment Search Tool. J Mol Biol 215:403-410. https://doi.org/10.1016/S0022-2836(05)80360-2

42. Sanger F, Nicklen S, Coulson AR (1977) DNA sequencing with chain-terminating inhibitors. Proc Natl Acad Sci USA 74:5463-5467

43. Stucky BJ (2012) SeqTrace: a graphical tool for rapidly processing DNA sequencing chromatograms. J Biomol Tech 23:90-93. https ://doi.org/10.7171/jbt.12-2303-004

44. Darriba D, Taboada GL, Doallo R, Posada D (2012) jModelTest 2: more models, new heuristics and parallel computing. Nat Methods 9:772. https://doi.org/10.1038/nmeth.2109
45. Dong J-B, Cook FR, Zhu W (2014) Equine infectious anemia virus in Japan: viral isolates V70 and V26 are of North American not Japanese origin. Vet Microbiol 174:276-278. https://doi. org/10.1016/j.vetmic.2014.08.004

46. Cook RF, Leroux C, Issel CJ (2013) Equine infectious anemia and equine infectious anemia virus in 2013: a review. Vet Microbiol 167:181-204. https://doi.org/10.1016/j.vetmic.2013.09.031

47. Langemeier JL, Cook SJ, Cook RF, Rushlow KE, Montelaro RC, Issel CJ (1996) Detection of equine infectious anemia viral RNA in plasma samples from recently infected and long-term inapparent carrier animals by PCR. J Clin Microbiol 34:1481-1487

48. Cappelli K, Cook RF, Stefanetti V, Passamonti F, Autorino GL, Scicluna MT, Coletti M, Verini-Supplizi A, Capomaccio S (2017) Deep sequencing and variant analysis of an Italian pathogenic field strain of equine infectious anaemia virus. Transbound Emerg Dis 64:2104-2112. https://doi.org/10.1111/tbed.12631

49. Petropoulos C (1997) Retroviral taxonomy, protein structures, sequences, and genetic maps. In: Coffin JM, Hughes SH, Varmus HE (eds) Retroviruses. Cold Spring Harbor Laboratory Press, New York

50. Tu Y-B, Zhou T, Yuan X-F, Qiu H-J, Xue F, Sun C-Q, Wang L, Wu D-L, Peng J-M, Kong X-G, Tong G-Z (2007) Long terminal repeats are not the sole determinants of virulence for equine infectious anemia virus. Arch Virol 152(209-218):55

51. Cook RF, Leroux C, Cook SJ, Berger SL, Lichtenstein DL, Ghabrial NN, Montelaro RC, Issel CJ (1998) Development and characterization of an in vivo pathogenic molecular clone of equine infectious anemia virus. J Virol 72:1383-1393

52. McGuire TC, Leib SR, Lonning SM, Zhang W, Byrne KM, Mealey RH (2000) Equine infectious anaemia virus proteins with epitopes most frequently recognized by cytotoxic T lymphocytes from infected horses. J Gen Virol 81:2735-2739

53. Wang X, Wang S, Lin Y, Jiang C, Ma J, Zhao L, Lv X, Wang F, Shen R, Kong X, Zhou J (2011) Genomic comparison between attenuated Chinese equine infectious anemia virus vaccine strains and their parental virulent strains. Arch Virol 156:353-357. https ://doi.org/10.1007/s00705-010-0877-8

54. Zheng Y-H, Sentsui H, Kono Y, Ikuta K (2000) Mutations occurring during serial passage of Japanese equine infectious anemia virus in primary horse macrophages. Virus Res 68:93-98

55. Dong J-B, Zhu W, Cook FR, Goto Y, Horii Y, Haga T (2013) Identification of a novel equine infectious anemia virus field strain isolated from feral horses in southern Japan. J Gen Virol 94:360-365. https://doi.org/10.1099/vir.0.047498-0

56. Quinlivan M, Cook F, Kenna R, Callinan JJ, Cullinane A (2013) Genetic characterization by composite sequence analysis of a new pathogenic field strain of equine infectious anemia virus from the 2006 outbreak in Ireland. J Gen Virol 94:612-622. https://doi. org/10.1099/vir.0.047191-0

57. Capomaccio S, Cappelli K, Cook RF, Nardi F, Gifford R, Marenzoni ML, Passamonti F (2012) Geographic structuring of global EIAV isolates: a single origin for New World strains? Virus Res 163:656-659. https://doi.org/10.1016/j.virusres.2011.11.011

58. Gaudaire D, Lecouturier F, Ponçon N, Morilland E, Laugier C, Zientara S, Hans A (2017) Molecular characterization of equine infectious anaemia virus from a major outbreak in southeastern France. Transbound Emerg Dis 65:e7-e13. https://doi. org/10.1111/tbed.12657

59. Sharav T, Konnai S, Ochirkhuu N, Ts EO, Mekata H, Sakoda Y, Umemura T, Murata S, Chultemdorj T, Ohashi K (2017) Detection and molecular characterization of equine infectious anemia virus in Mongolian horses. J Vet Med Sci 79:1884-1888. https:// doi.org/10.1292/jvms.17-0202 